\title{
The Role of Demography, Geographical Constraints, and Land Regulations on House Price in Malaysia
}

\author{
Saizal Bin Pinjaman \\ Faculty of Business, Economics and Accountancy, Universiti Malaysia Sabah, Malaysia \\ E-mail: saizal@ums.edu.my
}

Sarma Aralas

Faculty of Business, Economics and Accountancy, Universiti Malaysia Sabah, Malaysia

\section{Debbra Toria Nipo}

Faculty of Business, Economics and Accountancy, Universiti Malaysia Sabah, Malaysia

Received: January 20, 2022 Accepted: March 2, 2022 Published: March 7, 2022

doi:10.5296/ber.v12i1.19475 URL: https://doi.org/10.5296/ber.v12i1.19475

\begin{abstract}
The current paper investigates the influence of demography, geographical constraints, and land regulation on house price in Malaysia based on the developers' perspective. A survey questionnaire was distributed among the real estate developers in the country and for the demographical factors, population growth, income, standard of living, and household confidence on future prices are identified to be important determinants. Meanwhile, in terms of land regulations, a majority of the developers believed that the cost of land acquisition, zoning regulations, and land statuses are important on house price setting. Apart from that, geographical constraints including land reclamation, forest clearing, and hillslope stripping are also considered by the developers. In ensuring that the house price remains affordable, land regulations on real estate development should be more relaxed to stimulate housing projects at lower costs. In addition, price speculation should also be monitored if not curbed so that the house price remains affordable particularly for the medium and low-income earners.
\end{abstract}

Keywords: House price, Demography, Geographical constraints, Land regulations

JEL Classification: J11, R31, R38 


\section{Introduction}

The housing market is one of the largest economic sectors in Malaysia with financing, for example is dominated by property loans particularly for home financing purposes. Delmendo (2021) said the size of the mortgage market in Malaysia was 43.3 percent of the country's total GDP in 2020 while a report released by Bank Negara Malaysia (2012) stated that 41 percent of the bank aggregate financing in 2012 was channeled for property development with turnover amounting to RM454.30 billion. Despite the economic downturn due to the Covid-19 pandemic, Valuation and Property Services Department (2020) claimed that a total of 295968 transactions worth RM119.08 billion were recorded in the property market in 2020 with RM65.87 billion of them involving residential property transactions. By state, Selangor was the highest number and value contributor to the national market share with 23.0 percent in the number of transactions and 33.0 percent in the value amounting to RM21.72 billion.

Due to the large scale of the housing market in Malaysia, any issue associated with the housing market is certainly able to influence the economic performance of the country (Pinjaman \& Kogid, 2019). Among the issues that are associated with the housing market in Malaysia is the high price levels which in turn leads to the affordability problem where people, especially the middle and low-income earners, are unable to buy properties. According to a paper prepared for the Khazanah Research Institute by Ismail et al. (2019), the Malaysian residential market has consistently exceeded the affordability threshold of 3.0 times median annual family income from 2002 to 2016 as indicated in Table 1. Kelantan, Sabah, Pulau Pinang, and Negeri Sembilan are the four Malaysian states classified as severely unaffordable.

Table 1. Median multiple affordability by states in Malaysia, 2002 - 2016

\begin{tabular}{|c|c|c|c|c|c|c|c|c|}
\hline State/Area & 2002 & 2004 & 2007 & 2009 & 2012 & 2014 & 2016 & Affordability Classification \\
\hline Kelantan & 5.1 & 5.4 & 4.4 & 4.5 & 6.2 & 7.1 & 5.5 & \multirow{4}{*}{$\begin{array}{l}\text { Severely unaffordable } \\
5.1 \text { and over }\end{array}$} \\
\hline Sabah & 6.3 & 6.7 & 10.0 & 6.2 & 5.8 & 5.6 & 5.5 & \\
\hline Pulau Pinang & 4.1 & 4.3 & 4.1 & 4.0 & 4.1 & 5.8 & 5.5 & \\
\hline Negeri Sembilan & 3.4 & 3.1 & 3.3 & 3.4 & 2.8 & 5.0 & 5.1 & \\
\hline Pahang & 5.0 & 4.2 & 3.7 & 3.9 & 3.8 & 5.3 & 5.0 & \multirow{8}{*}{$\begin{array}{l}\text { Seriously unaffordable } \\
4.1 \text { to } 5.0\end{array}$} \\
\hline Johor & 4.9 & 4.9 & 3.5 & 3.7 & 3.7 & 4.3 & 5.0 & \\
\hline Malaysia & 4.1 & 4.3 & 4.4 & 4.4 & 4.0 & 5.1 & 5.0 & \\
\hline Terengganu & 4.7 & 4.8 & 5.0 & 5.2 & 5.3 & 6.2 & 5.0 & \\
\hline Kuala Lumpur & 4.7 & 5.4 & 5.0 & 4.6 & 4.9 & 5.6 & 4.9 & \\
\hline Selangor & 3.7 & 3.5 & 3.6 & 3.6 & 3.6 & 5.2 & 4.7 & \\
\hline Perak & 3.9 & 4.1 & 3.5 & 3.5 & 3.3 & 5.1 & 4.6 & \\
\hline Kedah & 4.6 & 4.1 & 4.1 & 4.0 & 3.6 & 3.4 & 4.3 & \\
\hline Sarawak & N.A. & N.A. & 3.7 & 4.1 & 4.0 & 4.2 & 4.0 & \multirow{3}{*}{$\begin{array}{l}\text { Moderately unaffordable } \\
3.1 \text { to } 4.0\end{array}$} \\
\hline Perlis & 4.4 & 3.7 & 3.6 & 4.5 & 4.3 & 4.5 & 4.0 & \\
\hline Melaka & 3.4 & 3.5 & 2.9 & 2.9 & 2.6 & 3.1 & 3.1 & \\
\hline
\end{tabular}

Source: Ismail et al. (2019).

Note: 1. Median multiple affordability is determined based on the ratio of the median all-house price by the household median income.

2. N.A. refers to the non-availability of the data. 
The affordability then leads or translated into further issues among which is the failure of the real estate developers to sell their developed properties. Ling (2017) considers the mismatch between the price of newly launched properties and the affordability of buyers to cause many unsold properties. This is in line with the report issued by the Valuation and Property Services Department (2020) as shown in Table 2 which claimed that the number of unsold completed homes in the 4th quarter of 2020 in Malaysia alone was 29565 units with a value of RM18.92 billion. Johor is the state with the highest number of unsold completed units in the country with 7,030 units and worth RM5.48 billion. It was followed by Selangor with 4889 units, and Perak and Kuala Lumpur, with 3637 units and 3023 units respectively. In terms of value, the second highest is Selangor with RM4.29 billion, followed by WP Kuala Lumpur and Perak with RM2.92 billion and RM1.16 billion respectively.

Table 2. Residential market status, 2016 - 2020

\begin{tabular}{|l|c|c|c|c|c|}
\hline Status & 2016 & 2017 & 2018 & 2019 & 2020 \\
\hline Overhang & 14792 & 24738 & 32313 & 30664 & 29565 \\
\hline Unsold under construction & 64077 & 61882 & 80894 & 72692 & 71735 \\
\hline Unsold not constructed & 11622 & 12626 & 19865 & 16774 & 12975 \\
\hline
\end{tabular}

Source: Valuation and Property Services Department (2020).

A number of researchers believe that the increase in house prices may come from the non-economic fundamentals (Lahoz, 2007; Glaeser and Gyourko, 2018; Molloy, 2020). Glaeser et al. (2005) pointed that house price increase in the United States is caused by zoning and development permission. Meanwhile, Yanan (2017) argues that demographical factors can also contribute to the movement of the house price. Despite the various research pointing to the significance of non-economic fundamentals particularly the demography, geographical constraints, and land regulations on house price, there is a scarce analysis that have been conducted to identify the impact of these important factors in Malaysia. Among the very few studies that conducted similar analysis in the country are MacDonald (2011) and Kamal et al. (2016). MacDonald (2011) for example identify the influence of non-economic fundamentals including supply-side, demographic factors, and the role of planning. Nevertheless, MacDonald (2011) and Kamal et al. (2016) are focusing on the issue in the case of Pulau Pinang or Penang only while the influence of the said factors on the rest of the states in Malaysia were less investigated yet need to be analyzed to deepen the knowledge on this prolonged issue that is widespread across the country.

Due to the limited number of studies conducted on the topic in the country, the objective of this study is to examine the role of demography, geographical constraints, and land regulations on house prices in Malaysia. This study is important to be implemented as a source of reference for policymakers in formulating policies related to the housing market in the future as well as to contribute to the body of knowledge.

The remainder of this paper is organized as follows: Section 2 discusses previous literature on the role of demography, geographical constraints, and land regulations toward house prices. Meanwhile, Section 3 discusses the data as well as descriptive statistical approaches. Section 
4 presents the estimation findings, and Section 5 concludes the article.

\section{Literature Review}

\subsection{Theoretical Background}

A strand of literature analyzed the changes in house prices from the supply-side point of view. This strand of literature, according to Nakajima (2011), focuses on the inflexible character of housing supply, which is related to a longer time to build houses and land scarcity. Molloy (2020) studied the geographical aspect and found that real estate spending increased at a more challenging geographical position. This is consistent with the findings obtained by Ho and Ganesan (1998) who acknowledged that there is a negative relationship between land supply and house price levels. In addition to that, Ho and Ganesan (1998) also identified that an increase in land supply will bring forth a decrease in housing prices. Apart from the geographical aspect, the house price factor from the supply point of view can also be seen in the regulatory aspect. The study conducted by Glaesar et al. (2005) for example found that housing supply regulations have a relationship with the increase in house prices and it is in line with the findings obtained by Hilber and Vermeulen (2016) on the English planning system.

\subsection{Empirical Studies on House Price Determinants}

Glaeser and Gyourko (2018) conducted a study in the US and found that in a lightly regulated market with an increasing population and expanding economy, the home supply curve is relatively sloping. When demand increases, as a result, the high degree of competition among property developers can retain house prices at a level close to the minimum profitable production cost and in turn keeping the price at affordable levels. On the other hand, for a heavily regulated market with a growing economy, the housing supply curve is steeper and increased demand will lead to a higher price level relative to the minimum profitable production cost.

The situation analyzed by Glaeser and Gyourko (2018) is also described in more detail by Kendall and Tulip (2018) who said zoning regulations cause housing supply constraints and in turn increase house prices. Using the hedonic regression analysis method of house sale for urban areas in Australia, Kendall and Tulip (2018) found that development restrictions would lead to a significant increase in house prices over the cost of physical input supply. In Sydney, zoning elevated detached house prices 73 percent over marginal costs, 69 percent in Melbourne, 42 percent in Brisbane, and 54 percent in Perth, according to Kendall and Tulip (2018).

There are also several studies conducted to identify the effect of geographical constraints on the cost of house supply. Glaeser and Gyourko (2018) for example said that there is no reason to assume production costs are the same even though these markets use the same regulations because geographical conditions can make houses to become more expensive to build in certain areas. Using satellite-generated data, Saiz (2010) said that the existence of steep-sloped terrain significantly limits residential growth. Furthermore, in a land confined by topography, housing supply is considered inelastic. 


\section{Macrothink}

Another factor that caught the attention of researchers from the supply-side was the demographic factor. Examining the effects of this variable in Macau, Yanan (2017) for example found that factors such as age ratio, child dependency ratio, and marital status are important in influencing house prices in the area. It was also found that the impact of elders over the age of 65 for example is large for Macau while the increase in the proportion of the population under the age of 15 leads to an increase in the financial burden of the family as well as adversely affect house prices. In relation to that, another study conducted by Bujang et al. (2010) found that housing affordability is also influenced by other demographic factors such as the number of households, educational level, and household income.

\section{Data and Methodology}

The current research investigates the role of demography, geographical constraints, and land regulations on house prices in Malaysia from the developers' perspective by distributing survey questionnaires among real estate developers in the country. The study obtained 41 respondents with the list of developers is obtained from the Real Estate \& Housing Developers' Association (REHDA) Malaysia, the Sabah Housing and Real Estate Developers Association (SHAREDA), and Sarawak Housing and Real Estate Developers' Association (SHEDA).

The current research modified the research questionnaire derived by Kamal et al. (2016) and conducted a pilot test with professionals in the property market, including lecturers, surveyors, and estate agents to see the applicability of the questionnaire across the country. After the data collection process, data cleaning was conducted, tested, and analysed based on descriptive statistics using SPSS. 


\subsection{Respondents Background}

Table 3. Developers background information

\begin{tabular}{|c|c|c|c|}
\hline Variable & Description & Number of respondents & Percent \\
\hline \multirow[t]{3}{*}{ Position } & Assistant Manager & 20 & 48.8 \\
\hline & Manager & 19 & 46.3 \\
\hline & Senior Manager & 2 & 4.9 \\
\hline \multirow[t]{2}{*}{ Gender } & Female & 12 & 29.3 \\
\hline & Male & 29 & 70.7 \\
\hline \multirow[t]{3}{*}{ Ethnicity } & Bumiputra Sabah & 4 & 9.8 \\
\hline & Chinese & 22 & 53.7 \\
\hline & Malay & 15 & 36.6 \\
\hline \multirow[t]{3}{*}{ Education } & Bachelor & 25 & 61 \\
\hline & Diploma & 13 & 31.7 \\
\hline & Master & 3 & 7.3 \\
\hline \multirow[t]{4}{*}{ Work Experience (Years) } & 0 to 5 & 8 & 19.5 \\
\hline & 6 to 10 & 24 & 58.5 \\
\hline & 11 to 20 & 7 & 17 \\
\hline & over 20 & 2 & 4.9 \\
\hline \multirow[t]{2}{*}{ Type of Ownership } & Private Limited (Sdn. Bhd.) & 39 & 95.1 \\
\hline & Limited Co. (Bhd.) & 2 & 4.9 \\
\hline \multirow[t]{5}{*}{ Firm Establishment (Years) } & 0 to 5 & 2 & 4.9 \\
\hline & 6 to 10 & 7 & 17.1 \\
\hline & 11 to 20 & 10 & 24.4 \\
\hline & 21 to 30 & 12 & 29.3 \\
\hline & over 30 & 10 & 24.4 \\
\hline \multirow[t]{2}{*}{ Business Operation } & National & 8 & 19.5 \\
\hline & State & 33 & 80.5 \\
\hline \multirow[t]{4}{*}{ Project Type } & Commercial & 1 & 2.4 \\
\hline & Residential & 24 & 58.5 \\
\hline & Infrastructure & 1 & 2.4 \\
\hline & Mixed Projects & 15 & 36.6 \\
\hline
\end{tabular}

Most of the respondents are assistant managers with 48.8 percent and followed by managers and senior managers with 46.3 percent and 4.9 percent, respectively. In terms of gender, over 70 percent of the respondents are male while female is 29.3 percent. Chinese are the main respondents in terms of ethnicity with 22 out of 41 and then followed by Malay with 15 . Bumiputra Sabah also contributes to the questionnaire with 4 respondents. The majority of them are bachelor's degree holders with 25 respondents or 61 percent while diploma holders are 13 respondents or 31.7 percent. Only 7.3 percent or 3 respondents have master's degrees.

Out of all respondents, 8 of them have work experience within 5 years and more than half or 24 of the respondents have work experience from 6 to 10 years. For work experience between 11 to 20 years and more, the number of respondents is 7 and 2, respectively. The study also looked into the types of ownership of the developers with 95.1 percent or 39 of the respondents are working for private limited (Sdn. Bhd) firms and only 2 of the respondents are from limited co. (Bhd.).

Looking into the type of establishment of the firm, only 2 are established between 0 to 5 
years while 7 are established between 6 to 10 years. Most of the firms are established between 11 to 20 years and 21 to 30 years with 10 and 12 respondents, respectively. There are 10 firms that were established for over 30 years. The majority or 33 of the respondents are operating at the state level while 8 are at the national level. For property type, most of the respondents are venturing into housing projects with 24 respondents and then followed by mixed projects. There is 1 company each that is venturing into the commercial and infrastructure project, respectively.

\section{Result Analysis}

There are two general items of the questionnaire, namely demography, geographical constraints, and land regulations with 16 specific questions. The questionnaire is constructed based on a 5-point Likert scale from scale - 1 represents strongly disagree to scale - 5 represents strongly agree.

\subsection{Demography}

Table 4. Response on the role of demography

\begin{tabular}{|l|l|l|l|l|l|}
\hline Demography & Minimum & Maximum & Mean & Std. Deviation & $\begin{array}{l}\text { Majority } \\
\text { Scale }\end{array}$ \\
\hline $\begin{array}{l}\text { 1. A thorough market study was conducted } \\
\text { before deciding on the type of houses to develop. }\end{array}$ & 3 & 5 & 4.49 & 0.597 & 5 \\
\hline $\begin{array}{l}\text { 2. A thorough market study was conducted } \\
\text { on setting the house price }\end{array}$ & 3 & 5 & 4.49 & 0.553 & 5 \\
\hline $\begin{array}{l}\text { 3. Population growth was considered in } \\
\text { estimating the demand for house. }\end{array}$ & 2 & 5 & 3.78 & 0.759 & 4 \\
\hline $\begin{array}{l}\text { 4. Population growth was considered on } \\
\text { setting the house price. }\end{array}$ & 1 & 5 & 3.44 & 0.896 & 4 \\
\hline $\begin{array}{l}\text { 5. The age distribution was considered } \\
\text { in estimating the demand for house. }\end{array}$ & 2 & 5 & 3.41 & 0.865 & 3 \\
\hline $\begin{array}{l}\text { 6. The age distribution was considered on } \\
\text { setting the house price. }\end{array}$ & 1 & 5 & 3.12 & 1.005 & 3 \\
\hline $\begin{array}{l}\text { 7. The background of buyers was } \\
\text { considered in housing development. }\end{array}$ & 2 & 5 & 4.1 & 0.8 & 4 \\
\hline $\begin{array}{l}\text { 8. Household income influences was } \\
\text { considered on setting the house price }\end{array}$ & 2 & 5 & 4 & 0.592 & 4 \\
\hline $\begin{array}{l}\text { 9. The current standard of living was } \\
\text { considered on setting the house price }\end{array}$ & 2 & 5 & 4.07 & 0.787 & 4 \\
\hline $\begin{array}{l}\text { 10. The household confidence in future } \\
\text { prices was considered on setting the house price }\end{array}$ & 2 & 5 & 3.56 & 0.743 & 4 \\
\hline
\end{tabular}

There are 10 specific questions that are related to demography and as demonstrated in Table 4, a majority of the developers conducted a detailed market study before deciding on the type and the price of houses to develop with the mean score of 4.49 for both. Most of the developers also agree that population growth is taken into account and influences their decision in determining the demand and housing price with a mean score of 3.78 and 3.44, respectively. Surprisingly, a majority of the respondents either disagree or remain neutral in the impact of age distribution towards the housing price but consider the background of the buyers in developing housing projects as an important indicator. As indicated, the mean score 
of both questions that are related to age, namely Question 6 and 7 have a mean score of 3.41 and 3.12, respectively. The lower mean score for age implies that the factor is less important relative to other demographical factors.

With a mean score of 4.0 to 4.1 , many of the developers also agree that the background of the buyers, income, as well as the standard of living of the potential buyers, influences their decision in determining the housing price. Despite some responses given disagree on the impact of household confidence in future prices towards the decision of the developers on setting the house price, a majority still consider it as an important indicator with a mean score of 3.56. This suggests the possible implication of market speculation, particularly market confidence, as an important determinant of house prices in the country.

\subsection{Geographical Constraints and Land Regulations}

Table 5. Response on geographical constraints and land regulations

\begin{tabular}{|l|c|c|c|c|c|}
\hline Geography and land regulations & Minimum & Maximum & Mean & $\begin{array}{l}\text { Std. } \\
\text { Deviation }\end{array}$ & $\begin{array}{l}\text { Majority } \\
\text { Scale }\end{array}$ \\
\hline $\begin{array}{l}\text { 1. The cost of land acquisition influences our } \\
\text { decision on housing prices. }\end{array}$ & 3 & 5 & 4.49 & 0.597 & 5 \\
\hline $\begin{array}{l}\text { 2. Land zoning including land identification and } \\
\text { release influences our decision on housing price. }\end{array}$ & 3 & 5 & 4.59 & 0.547 & 5 \\
\hline $\begin{array}{l}\text { 3. Land re-zoning including changing the } \\
\text { land initial zone into residential purposes } \\
\text { influences our decision on housing price. }\end{array}$ & 2 & 5 & 3.93 & 1.034 & 4 \\
\hline $\begin{array}{l}\text { 4. The housing price on freehold land was } \\
\text { set higher than leasehold land. }\end{array}$ & 2 & 5 & 3.8 & 0.641 & 4 \\
\hline $\begin{array}{l}\text { 5. Geographical constraints including land } \\
\text { reclamation, forest clearing, and hillslope } \\
\text { stripping influence our decision on housing prices. }\end{array}$ & 1 & 5 & 3.68 & 0.907 & 4 \\
\hline $\begin{array}{l}\text { 6. Difficulty in acquiring tracts of land from } \\
\text { different land-owning groups influences our } \\
\text { decision on housing price. }\end{array}$ & 2 & 5 & 3.37 & 0.888 & 4 \\
\hline
\end{tabular}

On the geographical constraints and land regulations, there are 6 questions given to the developers as shown in Table 5. The questionnaire focuses on the influence of geographical and zoning constraints towards house price setting, and it is identified that a majority of the developers agree that the cost of land acquisitions and zoning influence their decision on housing price. A majority of the respondents strongly agree on both factors with a mean score of 4.49 and 4.59 , respectively.

The developers also agree that changing the land initial zone into residential purposes and the status of the land, either freehold or leasehold determine their decision on the housing price. The cost incurred in changing the zone of the land into residential purposes may cause the developers to set the price higher where the mean score is demonstrated to be 3.93. It is also indicated that the price is set to be higher for freehold than leasehold land with a mean score of 3.8 .

As indicated in Table 5, most of the developers agree that geographical constraints such as 
land reclamation, forest clearing, and hillslope stripping influence the house price which implies the cost incurred by the developers on the housing project with a mean score of 3.68. Finally, it is clear that acquiring tracts of land from different land-owning groups or individuals, which is evident in most of the urban areas across Malaysia, is an important factor in determining the decision of the developers on housing prices.

\section{Conclusion}

By referring to the findings, it is demonstrated that demography, geographical constraints, and land regulations are important determinants of house price in Malaysia and are in line with the supply-side theory of house price. In terms of demography, most developers agree that factors such as population growth, buyer's background, income, and standard of living are important determinants of house price. This is in line with the findings of previous researchers such as Bujang (2010) and Yanan (2017). Apart from that, it is also evident that the expectation on future prices is also an important factor of house price. This is an important discovery since the expectation, which can lead to price speculation, may be a contributing factor to the reason why house prices are above the income level and eventually lead to the issue of house affordability in Malaysia. According to Kahn (2008), sustained income growth is one of several fundamental variables that could lead to an increase in expectation.

Another contributing factor of house price is geographical constraints and land regulations, and this is similar to the argument of Glaesar et al. (2005), Glaeser and Gyourko (2018), and Molloy (2020). It is evident that both geography and regulations lead to the increase in housing development costs which is then causing the developers to set a higher house price. Factors such as land reclamation, zoning, land status, and other geographical constraints are said to be important factors considered by the developers in setting house prices. Another factor that is associated with land is the landowners where multiple landowners may set different financial and regulatory challenges to the developers to purchase the land. Getting each of the owners to agree with the prices offered for them individually and to change the initial zone to residential purposes for example may incur additional expenses to the developers. In supply-constrained land, particularly in the urban area, geography and land regulations can be a leading factor of house price.

The findings of the current research provide a significant contribution to the policymaking as it indicates the importance of demography, geographical constraints, and land regulations on house prices based on the developers' perspective. The significance of future price expectation in influencing the house price may suggest the importance of certain mechanisms to prevent price speculations. The ever-increasing demand for house for renting purposes or to sell after a certain period from the high-income earners who expect that the price will keep on increasing cause the house price to constantly increase and lead to a serious affordability issue particularly for the medium and low-income earners. Apart from that, certain land regulations should also be relaxed as it is proved to restrict future house development due to the cost incurred which may cause a severe house affordability issue in the country.

As a suggestion for future research, there may be other factors that could be explored from 
the macroeconomic perspective. This will broaden the perspective on factors that potentially explain the house price movement so that more precise policies can be constructed. Apart from that, the sample size could be increased since the findings of the current research are limited to its small sample size as it is conducted during the movement control order to control the spread of the Covid-19 pandemic in the country.

\section{Acknowledgments}

The authors would like to extend their sincere gratitude to the Ministry of Higher Education (MOHE) and Universiti Malaysia Sabah for supporting this work under the Fundamental Research Grant Scheme for Research Acculturation of Early Career Researchers (RACER/1/2019/SS08/UMS//3).

\section{References}

Bank Negara Malaysia. (2012). Laporan Kestabilan Kewangan dan Sistem Pembayaran 2012. Kuala Lumpur: Bank Negara Malaysia

Bujang, A. A., Zarin, H. A., \& Jumadi, N. (2010). The relationship between demographic factors and housing affordability. Malaysian Journal of Real Estate, 5(1), 49-58. [Online] Available: https://ascelibrary.org/doi/pdf/10.1061/\%28ASCE\%29CF.1943-5509.0000413

Delmendo, L. C. (2021). Malaysia's housing market continues to weaken, amidst oversupply. Global Property Guide. [Online] Available:

https://www.globalpropertyguide.com/Asia/Malaysia/Price-History

Glaeser, E. L., Gyourko, J., \& Saks, R. E. (2005). Why have housing prices gone up?. American Economic Review, 95(2), 329-333. https://doi.org/10.1257/000282805774669961

Glaeser, E., \& Gyourko, J. (2018). The economic implications of housing supply. Journal of Economic Perspectives, 32(1), 3-30. https://doi.org/10.1257/jep.32.1.3

Hilber, C. A., \& Vermeulen, W. (2016). The impact of supply constraints on house prices in England. The Economic Journal, 126(591), 358-405. https://doi.org/10.1111/ecoj.12213

Ho, W. K. O., \& Ganesan, S. (1998). On land supply and the price of residential housing. Netherlands Journal of Housing and the Built Environment, 13(4), 439-452.

https://doi.org/10.1007/BF02497028

Ismail, S., Wai, C. C. W., Hamid, H. A., Mustapha, N. F., Ho, G., Theng, T. T., Kamaruzuki, M. N., \& Firouz, A. M. M. (2019). Rethinking Housing: Between State, Market and Society: A Special Report for the Formulation of the National Housing Policy (2018-2025), Malaysia. Kuala Lumpur: Khazanah Research Institute.

Kahn, J. A. (2008). What drives house prices. Federal Reserve Bank of New York Staff Report, 345 .

Kamal, E. M., Hassan, H., \& Osmadi, A. (2016). Factors influencing the housing price: developers' perspective. International Journal of Humanities and Social Sciences, 10(5), 1676-1682. https://doi.org/10.5281/zenodo.1124527 
Kendall, R., \& Tulip, P. (2018). The effect of zoning on housing prices. Reserve Bank of Australia Research Discussion Paper. pp. 2018-03. https://doi.org/10.2139/ssrn.3149272

Ling, C. S., Almeida, S., Shukri, M., \& Sze, L. L. (2017). Imbalances in the property market. BNM Quarterly Bulletin, Quarter, 3, 26-32. [Online] Available:

https://www.bnm.gov.my/documents/20124/770509/p3_ba2.pdf

MacDonald, S. (2011). Drivers of house price inflation in Penang, Malaysia: Planning a more sustainable future. Penang Institute Research Paper. [Online] Available:

https://penanginstitute.org/wp-content/uploads/jml/files/research_papers/Drivers_of_house_p rice_inflation.pdf

Molloy, R., Nathanson, C., \& Paciorek, A. (2020). Housing supply and affordability: Evidence from rents, housing consumption and household location.

https://doi.org/10.17016/FEDS.2020.044

Nakajima, M. (2011). Understanding house-price dynamics. Business Review, Federal Reserve Bank of Philadelphia, Q2, 20-28. [Online] Available:

https://citeseerx.ist.psu.edu/viewdoc/download?doi=10.1.1.443.2026\&rep=rep1\&type=pdf

Pinjaman, S., \& Kogid, M. (2020). Macroeconomic Determinants of House Prices in Malaysia. Jurnal Ekonomi Malaysia, 54(1), 153-165.

https://doi.org/10.17576/JEM-2020-5401-11

Saiz, A. (2010). The geographic determinants of housing supply. The Quarterly Journal of Economics, 125(3), 1253-1296. https://doi.org/10.1162/qjec.2010.125.3.1253

Valuation and Property Services Department. (2020). Property market report 2020. Ministry of Finance Malaysia. [Online] Available:

http://rehda.com/wp-content/uploads/2021/07/JPPH-Property-Market-Report-2020.pdf

Yanan, S. (2017, January). The Impact of Demographic Structure on Housing Prices: Evidence from Macau. In 2017 International Conference on Economics, Finance and Statistics (ICEFS 2017). pp. 268-272. https://doi.org/10.2991/icefs-17.2017.30

\section{Copyright Disclaimer}

Copyright for this article is retained by the author(s), with first publication rights granted to the journal.

This is an open-access article distributed under the terms and conditions of the Creative Commons Attribution license (http://creativecommons.org/licenses/by/4.0/). 